of chromite at Kemi. This non-magnetic chromite ore, which is heavier than its surroundings, is associated with an anorthosite-serpentinito intrusion. It was possible to make both magnetic and gravimetric measurements for locating the ore-body, and residual gravity maps proved especially useful.

L. Granar (Sweden) explained a new compensation method developed by the Geological Survey of Swoden, and the apparatus for measuring the potential field around an oro-body which is charged by a commutated direct current. The apparatus is also suitable for conventional resistivity detorminations by means of direct current. A lecturo by $O$. Lindholm (Finland) dealt with magnetic permeability measurements at the Otanmäki mine. The Otanmäk Co. had developed a method and apparatus for carrying out permeability determinations in drill holes. Thus, information about the location and quality of the ore could be procured cheaply and quickly by means of magnetic measurements. During the period $1956-61$ a total length of $130 \mathrm{~km}$. of drill hole was investigated by this method in the Otanmäki mine. P. Singsaas (Norway) gave an account of the electromagnetic conductive measurements which had been usod in research into zinc-lead oro deposits in Mofjollot, Nordland fylko. During the survey electrical anomalies were observed, which suggested that the ore-body continued at least one thousand metres eastwards from the mine. This result was later confirmed by diamond drilling.

P. Taanila and T. Kangas (Finland) gave an account of the seismic depth-to-bedrock determinations by refraction methods carried out by the Oulujoki Co. 'The Oulujoki Co. had developed a new profilo interpretation method and a special slido-rule which makes it possible to do the practical calculations rapidly. In his talk, J. Huhta (Finland) establishod that a hammer seismograph, developed by Goophysical Specialities Co., in the United States, had been used with great success in Kolari, North Finland, for determination of depth of shallow surface layers.
Associated with the meeting was an exhibition of instruments in which $\mathrm{H}$. Jalander (Finland) presented the latest model of his electronic magnetometer, L. A. Levanto Co., Finland, presented a gradient magnetometer developed by them, and the Otanmäki Co., Finland, showed their magnetic measuring devices for measuremonts of drill holes.

At the business meeting different ways of improving inter-Scandinavian co-operation for developing prospecting methods were discussed. The meeting decided that the organizing committeo of the third Geophysicist's Conference should continue its work, changing its name to "The Planning Committee", and that its task would be to examine tho possibilities of founding a new Scandinavian organization, as well as the possibilities of publishing the lectures held at the Helsinki meeting in English. The members of the planning committee were Messrs. Malmqvist (chairman), Braekken, Puranen and Saxov.

The Geophysics Education Committee, appointed by the second Nordic Meeting for Mining Geophysicists, decided to continue its work, and, furthermore, various sections would deal with technical mapping probloms, the question of nomenclature, a Scandinavian gravimotric map, and scale-model oxperiments.

It was decided that the fourth Nordic Meeting for Mining Geophysicists would be held in approximately two years time, and A. Eriksen (Norway) was elected chairman of the organizing committeo, the members of which are Messrs. A. Breen (Norway), D. Malm. qvist (Swedon) and T. Siikarla (Finland).

The third Nordic Meeting for Mining Geophysicists was most successful, and the number of participants was much greater than at the two previous meetings, and also there was a large number of lectures. That these meetings serve their purpose, and that the interest in them is constantly growing among ore prospectors is obvious. The decisions mado by the meoting will do much to improve Scandinavian co-operation in the field of mining geophysics.

Maunu Puranen

\title{
MECHANISM OF GLASS POLISHING
}

$\mathrm{A}$ BIBLIOGRAPHY has been published recently by tho British Scientific Instrument Research Association on the subject of the polishing of glass*. The bibliography is the first product of a new programme of research on this topic. Although the first investigations of this subject go back some hundreds of years, it is one of great industrial importaneo in both the optical and the plate glass industries. 'The new 'float' glass process removes the nood for polishing and is a successful but courageons and expensive development; in tho United States important progross seoms to havo been made by 'chemical' polishing. This process involves the introduction of materials such us potassium fluoride into tho polishing slurry and has been claimed to reduce the polishing time by a factor of ten. In spite of these new developments, a fresh investigation in the difficult ficld is to be wolcomed.

For many years polishing was regarded as a microgrinding process in which glass was removed by a

* British Scientine Instrument Research Association. B.S.I.R.A. Recearch Report $R, 267$ : The Mechanisms of Glass Polishing-a History and 13íbliography. By Dr. D. C. Cornish. Pp. iv +70 (Chislehurst. Kent: British Scientific Instrument Research Associa tion, 1961.) pulling or cutting action of the polishing grains on a scale too small to reveal itself in the microscope. At the beginning of this century the idea was introduced of a plastic doformation of the surface with glass being removed from high spots to fill hollows; a similar suggostion was that undor the high local pressures set up in the polishing process, tomperatures werc reached locally at which the glass became molten. In the nineteen-thirties the possibility of chomical reaction playing a part bogan to find favour. F. W. Preston, for example, stressed the importance of reactions betwoen the glass and the water usod in polishing. A book published in the U.S.S.R. in 1946 recorded a large volume of work on the ion-exchange reaction between the surface of the glass and the polishing slurry. Two of the latost references in tho bibliography show that the Association is already actively engaged experimentally on this phase of the subject.

Iike other apparently simple industrial arts, the polishing of glass is a very complex phenomenon which still demands very caroful scientific work for its elucidation.

R. W, DOUGLAS 